\title{
Characterization of traditional healers in the mountain forest region of Kahuzi-Biega, South-Kivu, DR Congo
}

\author{
Chantal Shalukoma ${ }^{(1,2)}$, Pierre Duez ${ }^{(3)}$, Joseph Bigirimana ${ }^{(1)}$, Jan Bogaert ${ }^{(4)}$, \\ Caroline Stévigny ${ }^{(2)}$, Célestin Pongombo ${ }^{(5)}$, Marjolein Visser ${ }^{(1)}$
}

\footnotetext{
(1) Université libre de Bruxelles. Faculty of Sciences. Research Unit of Landscape Ecology and Plant Production Systems. CP 264/2. Boulevard du Triomphe.BE-1050 Brussels (Belgium).E-mail: chantalshalukoma@gmail.com, shaluko@ulb.ac.be (2) Université libre de Bruxelles. Faculty of Pharmacy. Department of Pharmacognosy, Bromatology and Human Nutrition. CP 205/09. Boulevard du Triomphe. BE-1050 Brussels (Belgium).

(3) Université de Mons. Faculty of Medicine and Pharmacy. Department of Therapeutic Chemistry and Pharmacognosy. Avenue Maistriau, 19. BE-7000 Mons (Belgium).

(4) Université de Liège - Gembloux Agro-Bio Tech. Unité Biodiversité et Paysage. Passage des Déportés, 2. BE-5030 Gembloux (Belgium).

(5) Université de Lubumbashi. Faculty of Veterinary Medicine. Department of Pharmacology, Toxicology and Therapeutics. BP 1825. Lubumbashi (Democratic Republic of Congo).
}

Received on October 15, 2014; accepted on December 4, 2015.

Description of the subject. Several ethnobotanical studies have demonstrated links between traditional medicine practices and the ethnicity and geographical location of healers, while many others have concluded the opposite. This study deals with the typology of traditional healers in the mountain region of Kahuzi-Biega.

Objectives. The goal is to understand whether the typology of traditional healers is related to their inter-ethnic and inter-zonal differences, based on diseases treated and plants used.

Method. Ethnobotanical surveys were conducted using the "PSSVV" method. This involved 88 traditional healers recognized as "specialists" in 33 villages adjacent to the forest of Kahuzi-Biega, in DR Congo. Multivariate analysis (clustering, ordination, Mantel test, IndVal) were applied to establish typologies of traditional healers.

Results. Multivariate analyses showed that ethnicity and geographical location did not explain the practices and knowledge of healers. However, by using the IndVal method, differences were observed in their degree of specialization. Non-specialized healers $(70 \%)$ could be distinguished from specialized healers (30\%). Two clear groups of specialists emerged; those who treat bone trauma and those who treat obstetric-gynecological complaints. The Mantel correlation test revealed a positive association $(r=0.134, p<0.05)$ between the "healers-plants" and "healers-diseases" matrices. This indicates that healers who treat similar diseases use similar herbs. Both typologies have shown their preferences for forest species $(81 \%)$, especially trees $(51 \%)$.

Conclusions. This exploratory study suggests that traditional healers are characterized based on their specializations. This result helps in creating strategies to preserve local traditional knowledge and apply it to the conservation of species.

Keywords. Ethnobotany, forest resources, drug plants, indigenous knowledge, typology, human pathology, Democratic Republic of Congo.

\section{Caractérisation des tradipraticiens de la région de forêt montagneuse de Kahuzi-Biega, sud-Kivu, RD Congo}

Description du sujet. Plusieurs études ethnobotaniques ont démontré des liens entre les pratiques de la médecine traditionnelle et l'identité ethnique et géographique des tradipraticiens, de nombreuses autres ont montré l'inverse. Cette étude porte sur la typologie des tradipraticiens de la région de forêt montagneuse de Kahuzi-Biega.

Objectifs. L'objectif est de comprendre si la typologie des guérisseurs traditionnels est liée à leurs différences inter-ethniques et inter-zonales sur base des maladies traitées et des plantes utilisées.

Méthode. La méthode «PEEVV » a permis de mener des enquêtes ethnobotaniques auprès de 88 tradipraticiens de 33 villages de la région de Kahuzi-Biega en RD Congo. Les analyses multivariées (classification, ordination, Mantel test, IndVal) ont permis d'établir la typologie des tradipraticiens. 
Résultats. L'origine ethnique et géographique n'explique pas les groupements des tradipraticiens. La méthode IndVal a montré que leur typologie est basée sur leurs "spécialités » : les tradipraticiens modérément spécialisés (70 \%) et les tradipraticiens hautement spécialisés $(30 \%)$. De ces derniers, deux groupes se distinguent nettement, ceux qui traitent le traumatisme des os et ceux qui traitent les troubles des organes reproducteurs. La corrélation positive de Mantel $(r=0,134, p<0,05)$ entre les matrices «tradipraticiens-plantes » et «tradipraticiens-maladies» a suggéré que les tradipraticiens qui soignent les mêmes maladies utilisent en grande partie les mêmes plantes dans leurs pratiques médicales. Les deux typologies ont montré une préférence pour les espèces forestières $(81 \%)$, en particulier les arbres $(51 \%)$.

Conclusions. Cette étude exploratoire suggère que la typologie des tradipraticiens est basée sur leurs niveaux de spécialisations et non sur leurs différences ethniques et géographiques. Ce résultat est utile pour préserver les connaissances locales et les rendre utiles pour la conservation des espèces.

Mots-clés. Ethnobotanique, ressource forestière, plante médicinale, connaissance indigène, typologie, pathologie humaine, République Démocratique du Congo.

\section{INTRODUCTION}

Throughout the world, traditional medicine is regarded as a precious heritage, particularly for communities in developing countries. Its importance is well established on the African continent where about $80 \%$ of the population mainly relies on herbs for their primary health care (WHO, 2002). Despite large amounts of natural resources, people in the Democratic Republic of Congo (DRC) are still marked by poverty and insecurity (PNUD, 2009). The use of traditional medicine increased in the area since the start of the armed conflict in Eastern DR Congo in 1996 (Shalukoma, 2008). Indeed, in the province of South-Kivu in general, access to a modern healthcare system is limited. While World Health Organization (WHO) standards prescribe at least one doctor per 10,000 inhabitants, in South-Kivu there is one doctor per 27,699 inhabitants (PNUD, 2009). However, the population's demand for medicinal herbs exerts considerable pressure on vegetation, especially in protected areas (Mbayngone et al., 2011). Loss of plant species and biodiversity could be a direct consequence of the lack of regulation of the plants used in traditional medicine in many African countries. Thus, ethnobotanical studies are essential for understanding needs and helping decision-making when it comes to sustainable conservation of local flora.

Traditional medicine remains a complex field. It is based on traditions, pragmatism and knowledge, transmitted orally without being scientifically proven. Over time, however, pharmacological and clinical studies have researched and shown the effectiveness of many traditional practices (Sofowora, 2010). Fassin (1990) pointed out this complexity of traditional medicine. It is focused on disease but also involves institutions and players beyond the scope of the body and health.

To unravel the complexity of traditional medicine when compared with conventional medicine, anthropologists developed different typologies of medicine, depending on the knowledge they were referring to. Dunn (1976) developed an interesting typology that talked about medicine as being "local" (e.g. which can re-group traditional African practices), "regional" (e.g. comprising Arabic, Chinese and Indian medicines) and "cosmopolitan" (those based on a modern understanding of biology). Compared with Dunn, Kleinman (1980) classified:

- "popular medicine" as based on the family circle and neighbors to whom self-medication is primordial;

- "folk medicine" as practiced by traditional healers who are non-professionals, but specialists in their field;

- "professional medicine", like Ayurveda and Unani in Asia.

Unlike popular traditional medicine, specialized traditional medicine is used for certain specific health issues that are chronic and difficult to treat (Shalukoma, 2008).

Specialized traditional healers are recognized as such by their communities, due to their competence in the care of a given category of diseases (Fassin, 1990; Sofowora, 2010). Often, their knowledge is acquired through apprenticeship, however, they protect certain knowledge they consider too "secrets" in their practices. This secrecy limits the transmission of knowledge between healers, even along bloodlines (Pfeiffer et al., 2005; Kouakou, 2013). A paradox was pointed out in literature on discriminatory factors among traditional healers. Some ethnobotanical studies made the link between traditional medicine and culture on the one hand (Phillips et al., 1993; Reyes-Garcia et al., 2006; Signorine et al., 2009; Kasika et al., 2015) and between traditional medicine and geographical location on the other (Pardo-de-Santayana et al., 2007; Mutheeswaran et al., 2011). Moerman et al. (1996, 1999) and Heinrich et al. (1998) pointed out that studies were often focused on one ethnic group, one taxonomic group or botanical genus, and rarely considered the use of plants across cultures. Pfeiffer et al. (2005) argued that transmission of knowledge is influenced by geographical origin, local culture and gender. Finally, Augereau (2008) 
pointed out that each ethnic group has its own medicine deferential to the local flora and environment, and establishes its own rules regarding the recognition of plants properties.

However, there is also a body of research showing that significant links between culture and medicinal practices do not exist. Moerman et al. (1999) showed a remarkable trend of similarity in the use of certain medicinal plants, regardless of geographical location, of traditional healers in Chiapas, North America, Korea and Kashmir. Sop et al. (2012) demonstrated that the use of herbs as medicine was not culturally influenced among the Fulani, Samo and Mossi groups in Burkina Faso.

This study focuses on the knowledge and practices of specialist traditional healers from four ethnic groups, Batwa, Havu, Shi and Tembo, located in Kalehe and Kabare territories, respectively, around the mountain forest of Kahuzi-Biega. This forest is home to many flora and fauna species, including the endangered lowland gorilla (Gorilla berengei graueri) and the threatened eastern chimpanzee (Pan troglodytes schweinfurthii). It also possesses a very important ethno-medicinal potential. An understanding of the local practices of healers will help in defining conservation priorities and implementing long-term management strategies for species in a forest region heavily burdened by human activities (Sop et al., 2012).

The main objective of this study is to understand the factors structuring the basic organization of healers through the traditional medicinal practices recorded in the area, in order to preserve local knowledge and make use of it in the implementation of strategies for sustainable species conservation. We hypothesize that the ethnic affiliations and geographical locations of healers are significant structuring factors.

\section{MATERIALS AND METHODS}

\subsection{Study site}

Surveys were conducted around the mountain forest of Kahuzi-Biega in the province of South-Kivu, in Eastern DRC (Figure 1). The $600 \mathrm{~km}^{2}$ park, created in 1970 to protect the lowland gorillas, covers lowland forest $(600 \mathrm{~m}-1,200 \mathrm{~m}$ a.s.1.) and rainforest mountain $(1,700 \mathrm{~m}-3,308 \mathrm{~m}$ a.s.1.), which are connected by an ecological corridor (ICCN, 2009). The park, a world heritage site, has been endangered since 1997 (ICCN, 2009) due to the human pressure. The highland region of the park is characterized by mountains. The climate is of the afromontane type, with a maximum annual precipitation of up to $1,900 \mathrm{~mm}$ (Fischer, 1993). The main ethnic groups are Havu (Kalehe territory), Shi (Kabare territory and Kalehe territory, Kalonge axis), Tembo (Kalehe territory, Bunyakiri axis) and Batwa (located in both localities).

\subsection{Ethnobotanical surveys}

An ethnobotanical survey was conducted between 2010 and 2012 to collect data on traditional healers, pathologies treated and plants used. To ensure the reliability of data, we developed a methodology that is helpful, but demanding in terms of resources and time. This so-called "PSSVV" study was conducted in four steps (Figure 2): Pre-survey (PS), Survey (S), Data Verification (V) and Data Validation (V). The field investigations were affected by the precarious security situation in the study region. The sampling was exhaustive because the number of specialist healers in the region is limited. A total of 88 recognized healers was identified during pre-survey sessions. They all agreed to collaborate on the study. At their request, interviews were done individually. To motivate respondents, the purpose of the study was largely explained. A cash gift of appreciation was given after interviews, generally up to 50 USD, representing the value of a goat with reference to the culture. Interviews comprised questions relating to the identification of healers, the main diseases they treat and the plants they use to heal these diseases. The triangulation method, which enables the cross-checking of data (Guillemont, 2006), was used to check the reliability of data collected in different localities. Data relating to diseases and diagnosis (symptoms and/or physiological effects) were verified and, when necessary, clarified by health agents in hospitals and local health centers.

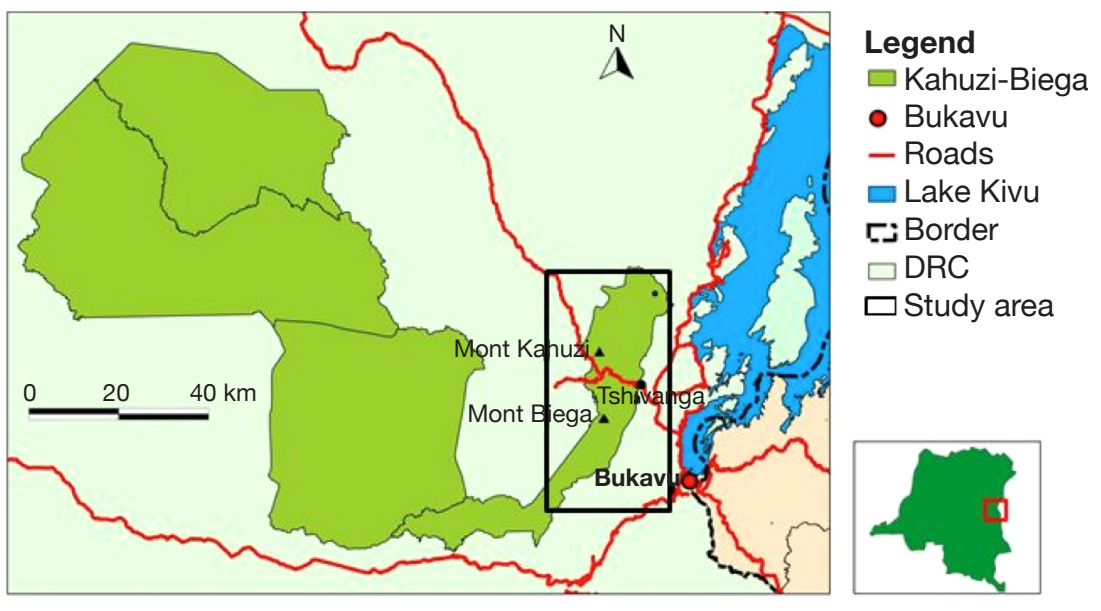

Figure 1. Study area: Kahuzi-Biega National Park - Zone d'étude : Parc National de Kahuzi-Biega. 


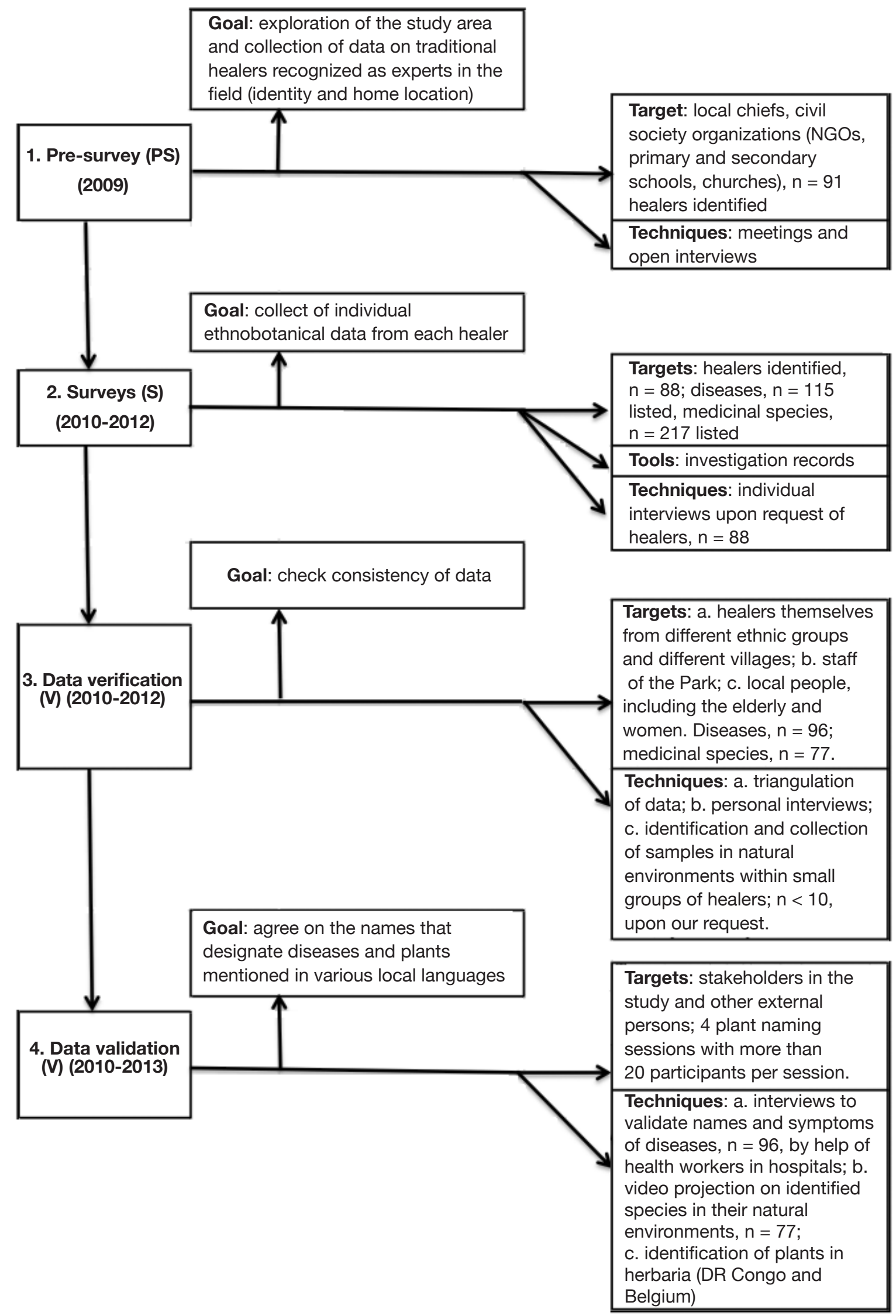

Figure 2. Schematic presentation of the ethnobotanical method "PSSVV" used around the Kahuzi-Biega National Park - Présentation schématique de la méthode ethnobotanique «PEEVV» utilisée autour du Parc National de Kahuzi-Biega. 
"Diseases" were then classified into the different "use categories" according to Cook (1995). In contrast with the very complex WHO system for the International Classification of Diseases (ICD), this practical categorization serves to group diseases depending on whether they affect a given system of the human body, allowing an easier understanding of healers' descriptions of treated diseases and symptoms. During interviews concerning herbs, a citation was considered as a "use score" (Treyvaud-Amiguet et al., 2005). These "use scores", once recorded from healers, were verified with different sources and through different channels to ensure correspondence with listed plants, their scientific names and their vernacular names. Species mentioned in the various local languages, including Mashi, Kitembo, Kihavu, and sometimes Kirega, had to be identified and collected during forest excursions. Following Ichikawa et al. (2003), the correct identification of species can only be done in their natural environment. Forest excursions were conducted with small groups of healers, depending on the affinities between them. Other village members and park technical staff were consulted on the names of cited herbs. Slides of identified herbs were projected with different groups of healers to confirm and complete the botanical list. The identification of samples was done in herbaria of the Centre de Recherche en Sciences Naturelles, CRSN/Lwiro (DRC) as well as in the Herbarium and Library of African Botany, BRLU/ ULB and in Meise Herbarium (Belgium). The naming system of the flora of Rwanda and from the lists of flowering plants of tropical Africa was applied (Lebrun et al., 2006). Formal and informal interviews with healers, various discussions with all study stakeholders and excursions into the forest were made possible by the collaboration established during the work.

\subsection{Data analysis}

To determine whether there is a significant difference between healers on the basis of diseases treated and plants used, we performed cluster analysis and ordination, identified indicator species through the IndVal method and carried out a $\mathrm{Chi}^{2}$ test based on the ethnicity and geographical location of healers. The analyses were based on two distance matrices, a binary matrix of 88 healers $\times 96$ diseases and a semi-quantitative matrix of 88 healers $x 77$ plants. For the binary matrix, data were represented by values " 1 " or " 0 ," depending on whether the healer treated the disease or not. For the second matrix, the numbers at the intersection of a plant and a healer represented the number of times one and the same species was mentioned to treat one or several diseases. The mentions of organs used for each species were collected qualitatively for documentation purposes.
The survey information was summarized by multivariate analysis using the software for ecology, PC-Ord 5.0 (McCune et al., 2002). In ecology, classification organizes community types depending on their calculated similarities or dissimilarities with distance measures and ordination methods, to improve the understanding of relations between species and environments (McCune et al., 2002). In this study, the relations concern healers with their plants used and diseases treated. The groups were discriminated by ascending hierarchical classification with the flexible-beta clustering method $(\beta=-0.25)$ associated with the Sørensen similarity index. Non-Metric Multidimensional Scaling (NMMS) was applied to both matrices, healers $\mathbf{x}$ diseases and healers $\mathbf{X}$ plants. The autopilot mode of the NMMS enabled 50 iterations of real data to be compared with 50 iterations of random data to select the dimensionality. To find an acceptable solution, 200 iterations were performed on the stability criterion of 0.00001 , with two dimensions. Indicator species and indicator diseases were identified for each group of healers, based on the IndVal method (Dufrêne et al., 1997) available in the software PC-Ord, 5.0 (McCune et al., 2002). In ecology, this procedure combines the relative abundance and relative frequencies of species to identify in each group the indicator species and their values (0-100\%). In this study, the statistical significance of these indicator values for each species or disease was evaluated by a Monte Carlo method with 5,000 randomizations, with a threshold $\alpha=0.05$. Healer groups were named based on their indicator species or diseases which obtained maximum and significant indicator values. The top two were considered for diseases and the top three for plants.

Correlations between distance matrices of healersdiseases (binary) and healers-plants (abundance) were calculated using a Mantel test (Mantel, 1967; McCune et al., 2002) and the Sørensen distance measure.

\section{RESULTS}

\subsection{Diversity of diseases treated as a basis for healers' typology}

A total of 96 diseases grouped into 18 categories (Appendix 1) were reported to be treated by specialized healers around the park. The most important disease classes were infectious (14\%), digestive (14\%) and genitourinary disorders $(13 \%)$.

Three groups of healers were identified from cluster analysis (Figure 3): group 1 was correlated to the two NMMS ordination axes, while groups 2 and 3 showed a better correlation with axis 2 (Figure 3). The two extracted axes represent $20 \%$ of the total variance, $9 \%$ 
Shalukoma Ch., Duez P., Bigirimana J. et al.
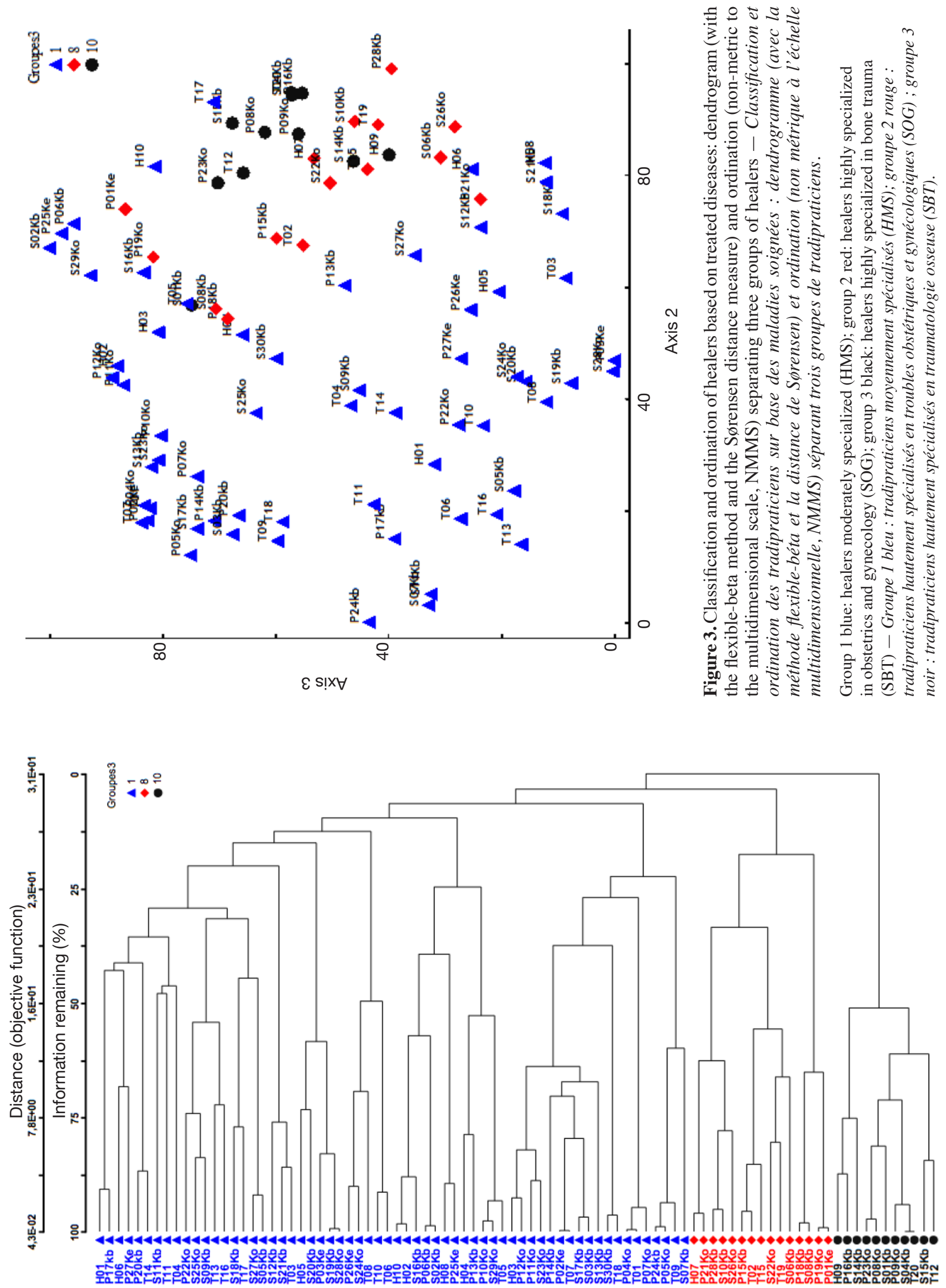
being explained by axis 2 and the remaining $11 \%$ being expressed by axis 3 .

Indeed, the three identified groups of healers were not related to their ethnic affiliation $\left(x^{2}=1.33 ; d f=6\right.$; $p>0.05)$ or to the geographic location of their homes $\left(x^{2}=1,86 ; d f=6 ; p>0.05\right)$. The differentiation of these three groups is instead explained by the specialization of healers in the treatment of the diseases, according to the indicator value analysis (Table 1).

Group 1 contains healers moderately specialized (HMS). They are recognized specialists but treat a wide range of diseases ( $51 \%$ of diseases treated; zero indicator disease).

Group 2 consists of healers highly specialized in obstetrics and gynecology (SOG), treating about $25 \%$ of diseases, mainly sexual impotence (IV [indicator value $]=38.8 \%)$, uterine prolapse $(I V=37.6 \%)$, gastric ulcer $(I V=31.3 \%)$ and threatened abortion $(I V=28.0 \%)$.

Group 3 consists of healers highly specialized in bone trauma (SBT). The SBT cares for $24 \%$ of diseases, mainly comprising fontanel anomalies $(I V=$ $21.2 \%)$ and fractures $(I V=92.2 \%)$.

\subsection{Diversity of medicinal plant species as the basis for identifying typology of healers}

A total of 77 medicinal species was recorded from the healers involved in the study. These species represented 72 genera and 41 botanical families (Appendix 2). The Asteraceae family was the most important, with 10 genera and 13 species, representing $17 \%$ of the total diversity. Among the morphological types identified in the practices of healers, trees were the most used $(51 \%)$, followed by herbaceous plants $(22 \%)$, shrubs $(21 \%)$ and vines $(6 \%)$ (Figure 4). With about $81 \%$ of the species being extracted from the

Table 1. Indicator diseases for discriminated groups of healers - Maladies indicatrices des groupes de tradipraticiens.

\begin{tabular}{llcl}
\hline Group & $\begin{array}{l}\text { Indicator } \\
\text { diseases }\end{array}$ & $\begin{array}{l}\text { Indicator } \\
\text { value }(\%)\end{array}$ & $\boldsymbol{p}$ \\
\hline HMS & - & 0 & 0 \\
\hline SOG & Sexual impotence & 38.8 & 0.001 \\
& Uterine prolapse & 37.6 & 0.003 \\
& Threatened abortion & 28.0 & 0.006 \\
\hline SBT & Fontanelle & 21.2 & 0.013 \\
& Fracture & 92.2 & 0.001 \\
\hline
\end{tabular}

HMS: healers moderately specialized - tradipraticiens moyennement spécialisés; SOG: specialists of obstetrics and gynecology - tradipraticiens spécialistes des troubles obstétriques et gynécologiques; SBT: specialists of bone trauma - tradipraticiens spécialistes des traumatismes des os.
Kahuzi-Biega, this forest was the harvesting location most frequented by healers. The remaining plants were collected from fallows (17\%) and fields (2\%). Among the medicinal species cited, Prunus africana and Autranella congolensis are listed as endangered species, due to their heavy exploitation for timber and bark for medicinal purposes (IUCN, 2015). However, not indicator species of any group.

Four groups of healers were identified from the cluster analysis of the 88 healers $x 77$ plants matrix (Figure 5). The two extracted axes represent $24 \%$ of the total variance, $11 \%$ being explained by axis 2 , and the remaining $13 \%$ being expressed by axis 3 .

Again, the relationship of these groups with ethnic affiliation $\left(x^{2}=6.62 ; d f=9 ; p>0.05\right)$ as well as with geographic location $\left(x^{2}=6.82 ; d f=9 ; p>0.05\right)$ of healers was insignificant. Instead, the species harvest site seemed to differ between these groups of healers.

Group 1 comprises healers using cultivated multiuse species (UCMUS). The indicator species of this group are Aloe barbadensis Mill. $(I V=28.6 \%)$, Baissea multiflora A.DC. $(I V=14.7 \%)$ and Plantago palmata Hook.f. $(I V=19.2 \%)$. The first two species have multiple uses in traditional medicine and are widely accessible. Plantago palmata is cultivated and sometimes used as an ornamental plant.

Group 2 comprises healers using forest multiuse species (UFMUS). It is indicated by 11 species

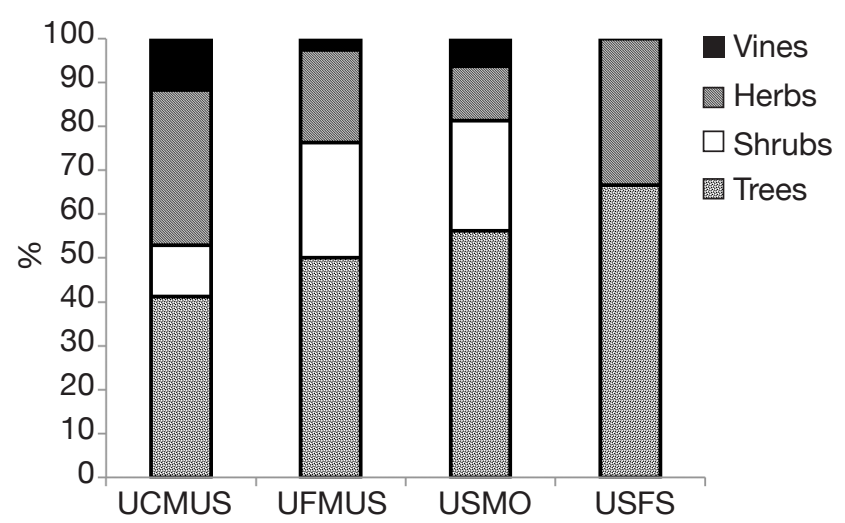

Figure 4. Proportions of morphological types of medicinal species used by discriminated groups of healers around the Park - Proportions des types morphologiques des espèces médicinales utilisées par les groupes de tradipraticiens dans le Parc.

UCMUS: healers using cultivated multiple uses species tradipraticiens utilisant des espèces cultivées à usages multiples; UFMUS: healers using forest multiple uses species -

tradipraticiens utilisant des espèces forestières à usages multiples; USMO: healers using species of mixed origins - tradipraticiens utilisant des espèces d'origine mixte; USFS: healers using species from secondary forests - tradipraticiens utilisant des espèces de forêts secondaires. 
Shalukoma Ch., Duez P., Bigirimana J. et al.
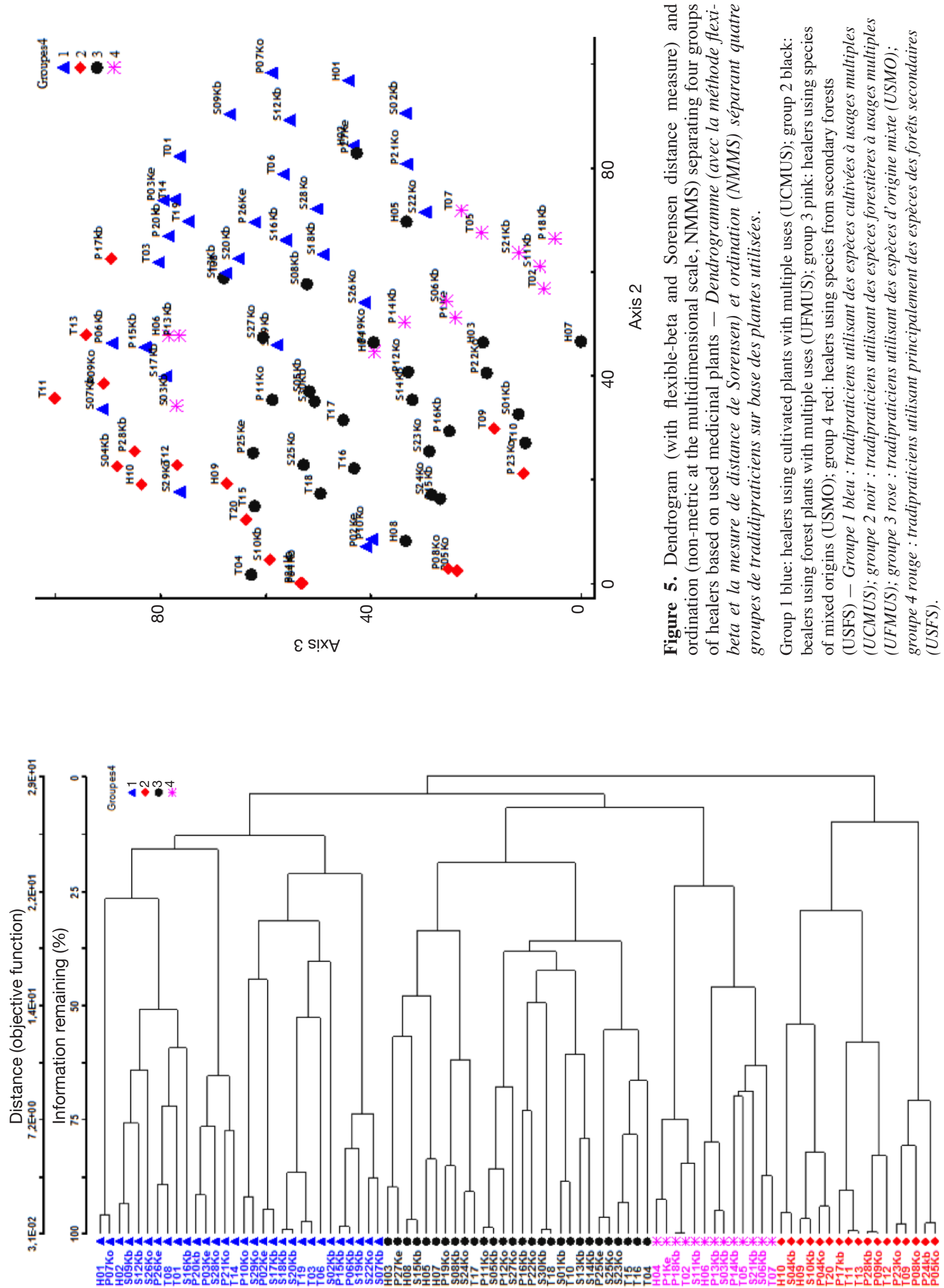
(Table 2) most of which are forest species (62\%) including Carapa grandiflora Sprague $(I V=26.2 \%)$, Piper capense L.f. $(I V=21.9 \%)$ and Anisopappus africanus (Hook.f.) Oliv. \& Hiern ( $I V=21.4 \%)$.

Group 3 consists of healers using species of mixed origins (USMO). The indicator species of this group are Tragia brevipes Pax $(I V=35.4 \%)$, Syzygium cordatum Hochst. ex Krauss $(I V=27.0 \%)$, Ensete ventricosum (Welw.) Cheesman $(I V=21.2 \%)$, Hibiscus noldeae Baker f. $(I V=20.2 \%)$, Zanthoxylum lemairei (De Wild.) $(I V=17.8 \%)$ and Kirkia acuminata Oliv. $(I V=15.8 \%)$. Half of all the species used by this group are wild and the remainder is ruderal.

Group 4 consists of healers using secondary forest plant species (USFS). Two indicator species are secondary forest species: Maesa lanceolata Forssk. (IV = $31.8 \%)$, Trema orientalis (L.) Blume $(I V=37.1 \%)$ and Drymaria cordata (L.) Willd. ex Schult. $(I V=41.0 \%)$.

\subsection{Consistency between typologies of healers identified from diseases treated and medicinal plants used}

The Mantel test revealed a significant correlation between the two typologies of healers based on diseases treated and medicinal species used $(r=0.134$, $p<0.05)$.

The superposition of typologies indicated that most healers using multi-use species (UCMUS and UFMUS) were healers moderately specialized (HMS). A large proportion of healers specializing in bone trauma (about $64 \%$ of SBT) corresponded to healers exploiting secondary forest plant species (USFS). About $27 \%$ of healers specializing in obstetrics and gynecology (SOG) were exploiters of species of mixed origins (USMO).

Table 2. Indicator species of four groups of healers - Espèces indicatrices de quatre groupes de tradipraticiens.

\begin{tabular}{|c|c|c|c|}
\hline Group & Indicator species & Indicator value (\%) & $p$ \\
\hline \multirow[t]{3}{*}{ UCMUS } & Aloe barbadensis Mill. & 28.6 & 0.002 \\
\hline & Plantago palmata Hook.f. & 19.2 & 0.033 \\
\hline & Baissea multiflora A.DC. & 14.7 & 0.049 \\
\hline \multirow[t]{11}{*}{ UFMUS } & Carapa grandiflora Sprague & 26.2 & 0.003 \\
\hline & Bidens pilosa $\mathrm{L}$. & 23.9 & 0.012 \\
\hline & Ageratum conyzoides $\mathrm{L}$. & 22.1 & 0.004 \\
\hline & Piper capense L.f. & 21.9 & 0.016 \\
\hline & Anisopappus africanus (Hook.f.) Oliv. \& Hiern & 21.4 & 0.004 \\
\hline & Parinari excelsa Sabine & 18.5 & 0.016 \\
\hline & Clerodendrum welwitschii Gurke & 17.9 & 0.006 \\
\hline & Entandrophragma excelsum (Dawe\&Sprague) Sprague & 17.9 & 0.020 \\
\hline & Myrianthus holstii Engl. & 17.9 & 0.010 \\
\hline & Alchornea hirtella Benth. & 14.3 & 0.036 \\
\hline & Begonia meyeri-johannis Engl. & 17,3 & 0.020 \\
\hline \multirow[t]{6}{*}{ USMO } & Tragia brevipes $\mathrm{Pax}$ & 35.4 & 0.001 \\
\hline & Syzygium cordatum Hochst. ex Krauss & 27.0 & 0.007 \\
\hline & Ensete ventricosum (Welw.) Cheesman & 21.2 & 0.011 \\
\hline & Hibiscus noldeae Baker f. & 20.2 & 0.028 \\
\hline & Zanthoxylum lemairei (De Wild.) P.G.Waterman & 17.8 & 0.016 \\
\hline & Kirkia acuminata Oliv. & 15.8 & 0.022 \\
\hline \multirow[t]{3}{*}{ USFS } & Drymaria cordata (L.) Willd. ex Schult. & 41.0 & 0.001 \\
\hline & Maesa lanceolata Forssk. & 31.8 & 0.002 \\
\hline & Trema orientalis (L.) Blume & 37.1 & 0.001 \\
\hline
\end{tabular}

UCMUS, UFMUS, USMO, USFS : see figure 4 - voir figure 4. 


\section{DISCUSSION}

Rather than ethnicity or geographic factor, healers were differentiated according to their degree and type of specialization. The plants they use are correlated with diseases they are specialized in.

\subsection{Diversity of diseases treated and the typology of traditional healers}

This study revealed the existence of two categories of healers around the mountain forest of Kahuzi-Biega: healers moderately specialized and healers highly specialized. The first category represents a large majority of healers $(70 \%)$, while the second represents a minority (30\%). Most moderately specialized healers have an expertise that encompasses many kinds of diseases, while healers highly specialized generally focus on only one group of diseases or on a specific mode of traditional practices. In districts of Abidjan, Manouan et al. (2010) found a similar pattern of a high proportion of non-specialized healers (79\%) and a low proportion of specialists. According to Kouakou (2013), many healers often lengthen their list of skills in order to be considered useful and honorable in their communities. However, the financial benefits of the profession also encourage people with limited knowledge to masquerade as healers. Accordingly, it is therefore important, with the help of the commitment of local communities, to differentiate real healers from those particularly motivated by money and power. This need for money might also encourage them to become more specialized in some category of diseases. The result is that they will not be so good at diagnosing and treating the variety of diseases prevalent in their communities.

\subsection{Diversity of medicinal plant species and typology of traditional healers}

In Kahuzi-Biega region, the use of trees by healers is a reality compared with other morphological types. This trend was reported in other regions in Africa, e.g. in Zinguinchor in Senegal (Diatta et al., 2013), for healers in South Omo, Ethiopia (Tolossa et al., 2013) and in Limpopo province, South Africa (Potgieter et al., 2012). This is explained by the fact that woody species generally present a higher concentration of secondary metabolites, notably alkaloids or saponins, compared with herbaceous species (Hladick et al., 1997). According to Bitsindou (1996), the significant use of bark in traditional medicine is linked to its often important role in the biosynthesis and storage of secondary metabolites, but also for its ease of collection and/or preservation, compared with other parts like roots, leaves or latex.
Healers prefer collecting plants from the forest, even when some species are available in villages. A similar attitude was reported in Madagascar by Rasoanaivo (2005), who found that plants have a high content of active ingredients as a result of growing in natural habitats. Collins et al. (2006) also noted that in TimorLeste cultures, healers prefer species from the forest. The trend is similar in Morocco, where medicinal species from forests have a higher cultural value than those collected in the village (Mehdioui et al., 2007). In other countries where forests are uncommon, such as Burkina Faso, healers prefer to collect medicinal plant species in gallery forests (Olivier et al., 2012).

\subsection{Consistency of typologies of traditional healers based on diseases treated and plants used}

Among the four ethnic groups studied around the forest of Kahuzi-Biega, the findings of this study suggest that medicinal practices are not influenced by either the ethnic group or geographical location of healers. Healers often use almost the same species to treat the same identified diseases. A similar observation was made in Beni and Lubero territories, where Kasika et al. (2015) found that specialist healers showed the convergence of use of species against recurrent diseases among Bantus and Pygmies groups. This may be explained by their expert knowledge of useful plants. Also, geographical proximity can enable similar access to the whole biodiversity in the area, including low forest and mountain rainforest. According to Saslis-Lagoudakis et al. (2014), the distribution and availability of plant species are controlled by local environmental conditions so that differences in culture and language represent no predispositions to the differences in practices and uses of medicinal plants.

\subsection{Implications of traditional healer typologies for species conservation}

Traditional medicine practitioners, moderately or highly specialized, are often consulted by local people for healthcare. They all use drugs from plants and a large proportion of these plants are obtained from wild sources and particularly from the forest. Thus, they can negatively impact species when plant collection methods do not respect sustainable harvesting requirements. According to Richter (2015), mechanical injuries caused by humans to trees left unharvested, in the long term, usually reduces wood quality because injuries often lead to fungal infection with subsequent wood discoloration and decay. During the harvesting of plant parts, in most cases, wounds and injuries can further increase the vulnerability of species by preventing recovery, while the forests are in the process of disappearing. Traditional practitioners also have a 
positive role to play as one of the stakeholders in the conservation of plant diversity. Their contribution is demonstrated and recognized through the practice of cultivating medicinal plant species (Cunningham, 1993). As long as a plant is known and successfully used by healers, it will be harvested. This suggests highlighting best practices and knowledge of traditional healers based on their specialties. Active involvement in ex situ conservation efforts is an alternative to protect a wide variety of plant species. Providing support for planting medicinal species in community gardens or incorporating them into crop fields constitutes some of the pathways for preserving wild woody species.

\section{CONCLUSIONS}

This study reveals the importance of knowing the basis of the organization of traditional practitioners in order to better understand localized traditional medicine. It has revealed that in the Kahuzi-Biega highland region, traditional medicine is not influenced by the ethnic affiliation or geographical location of healers. Based on diseases and plants used, this traditional medicine is mainly dependent on the healer's specialization. The study also suggests that traditional healers can be characterized on the basis of the type of their knowledge; as healers moderately or highly specialized. Healers moderately specialized use several plants to treat a great number of diseases and healers highly specialized use particular plants to treat a limited group of diseases. Two clear groups of healers highly specialized emerge: those who treat bone trauma and those who treat obstetric-gynecological complaints. Both typologies have associated preferences for forest species, especially trees.

The fact that (i) neither ethnic origin nor geographical location could structure the group of traditional healers and that (ii) plant use and disease specialization were correlated suggests we should consider them as one community sharing a common set of practices and a single body of knowledge. This result begs the question: to what degree of ethnic or geographical distance can knowledge be shared? In other words, from which point do these factors come into play. This exploratory study also raises contextspecific questions, such as why no other specializations have been encountered, how knowledge is shared between ethnic groups and different localities and if specific practices can be linked to the endangerment of specific species, such as endemic forest trees.

\section{Acknowledgements}

We thank CTB for the grant that supported our PhD studies. We also thank ICCN/KBNP and his partners GIZ, USFWS,
WCS and the Van Buuren Foundation for the material and financial support for field work. We are grateful for the collaboration of colleagues at PNKB, CRSN/Lwiro and MEISE. Most of all, we thank the population living around the forest of KBNP who agreed to collaborate and share their tremendous ethnobotanical knowledge.

\section{Bibliography}

Augereau J.M., 2008. Les plantes médicinales. In : Hallé F. \& Lieutaghi P., éds. Aux origines des plantes. Paris : Fayard, 170-201.

Bitsindou M., 1996. Enquêtes sur la phytothérapie traditionnelle à Kindamba et Odzala (Congo) et analyse des convergences d'usages des plantes médicinales en Afrique centrale. Thèse de doctorat : Université libre de Bruxelles (Belgique).

Collins S. et al., 2006. Quantitative ethnobotany of two east Timorese cultures. Econ. Bot., 60, 347-361.

Cook F.E., 1995. Economic botany data collection standard. Kew, UK: Royal Botanic Gardens.

Cunningham A.B., 1993. African medicinal plants: setting priorities at the interface between conservation and primary health care. Paris: UNESCO.

Diatta C.D., Gueye M. \& Akpo L.E., 2013. Les plantes médicinales utilisées contre les dermatoses dans la pharmacopée Baïnounk de Djibonker, région de Ziguinchor (Sénégal). J. Appl. BioSci., 70, 55995607.

Dufrêne M. \& Legendre P., 1997. Species assemblages and indicator species: the need for a flexible asymmetrical approach. Ecol.Monogr., 67, 345-366.

Dunn F.L., 1976. Traditional Asian medicine and cosmopolitan medicine as adaptive systems. In: Leslie C., ed. Asian medical systems. Berkeley, CA, USA: University of California Press, 133-158.

Fassin D., 1990. Maladie et médecine. Paris : Ellipses.

Fischer E., 1993. La végétation du Parc National de KahuziBiega (Sud-Kivu, Zaïre). Bonn, Allemagne : Université de Bonn.

Guillemont S., 2006. Gestion concertée des milieux ouverts au Parc National des Cévennes: représentations et pratiques des acteurs autour des prairies de fauche. Thèse de master : Université de Montpellier (France).

Heinrich M. et al., 1998. Medicinal plants in Mexico, healer's consensus and cultural importance. Social Sci. Med., 47, 1859-1871.

Hladik A. \& Hladik C.M., 1997. Signification écologique des teneurs en alcaloïdes des végétaux de la forêt dense : résultats des tests préliminaires effectués au Gabon. Terre Vie, 31, 515-555.

ICCN (Institut Congolais pour la Conservation de la Nature), 2009. Plan Général de Gestion du Parc National de Kahuzi-Biega. Kinshasa : ICCN.

Ichikawa M. \& Terashima H., 2003. A comparative ethnobotany of the Mbuti and Efe hunter-gatherers in the 
Ituri forest, Democratic Republic of Congo. Afr. Stud. Monogr., 24(1, 2), 1-168.

IUCN, 2015. Red list of threatened species. Gland, Switzerland: IUCN.

Kasika E.E.L., Vasombolwa K.V. \& Lejoly J., 2015. Contribution to the knowledge of plants used by Bantu and Pygmy healers in Beni and Lubero territories (Democratic Republic of Congo). J. Plant Stud., 4, 2.

Kleinman A., 1980. Patients and healers in the context of culture. Berkeley, CA, USA: University of California Press, 427.

Kouakou J.P., 2013. Perception et prise en charge $d u$ paludisme en médecine traditionnelle en Côte d'Ivoire. Paris : L'Harmattan.

Lebrun J.P. \& Stork A., 2006. Tropical African flowering plants, ecology and distribution. 2: EuphorbiaceaeDicapetalaceae. Genève, Suisse : Conservatoire et Jardin Botanique de la Ville de Genève.

Manouan N., N'Guessan B.B., Kroa E. \& Tiembré I., 2010. Identification des acteurs de la médecine traditionnelle en Côte d'Ivoire : cas du district autonome d'Abidjan. Ethnopharmacologia, 45, 75-79.

Mantel N., 1967. The detection of disease clustering and generalized regression approach. Cancer Res., 27, 209220.

Mbayngone E. \& Thiombiano A., 2011. Dégradation des aires protégées par l'exploitation des ressources végétales : cas de la réserve partielle de faune de Pama, Burkina Faso (Afrique de l'Ouest). Fruits, 66, 187-202.

McCune B. \& Grace J.B., 2002. Analysis of ecological communities. Gleneden Beach, OR, USA: MJM Software Design.

Mehdioui R. \& Kahouadji A., 2007. Étude ethnobotanique auprès de la population riveraine de la forêt d'Amsittène : cas de la Commune d'Imi n'Tlit (Province d'Essaouira). Bull. Inst. Sci. Rabat, Sect. Sci. Vie, 29, 11-20.

Moerman D.E., 1996. An analysis of the food plants and drug plants of native North America. J. Ethnopharmacol., 52, $1-22$.

Moerman D.E., Pemberton R.W., Keifer D. \& Berlin B., 1999. A comparative analysis of five medicinal floras. J. Ethnobiol., 19, 49-67.

Mutheeswaran S., Pandikumar P., Chellappandian M. \& Ignacimuthu S., 2011. Documentation and quantitative analysis of the local knowledge on medicinal plants among traditional Siddha healers in Virudhungagar district of Tamil Nadu. J. Ethnopharmacol., 137, 523533.

Olivier M., Zerbo P., Boussim J.I. \& Guinko S., 2012. Les plantes des galeries forestières à usage traditionnel par les tradipraticiens de santé et les chasseurs Dozo Sénoufo du Burkina Faso. Int. J. Biol. Chem. Sci., 6(5), 70-91.

Pardo-de-Santayana M. et al., 2007. Traditional knowledge of wild edible plants used in the northwest of the Iberian
Peninsula Spain and Portugal: a comparative study. J. Ethnobiol. Ethnomed., 3, 27-34.

Pfeiffer J.M. \& Butz R.J., 2005. Assessing cultural and ecological variation in ethnobiological research. The importance of gender. J. Ethnobiol., 25(2), 240-278.

Phillips O. \& Gentry A.H., 1993. The useful plants of Tambopata, Peru: I. Statistical hypotheses tests with a new quantitative technique. Econ. Bot., 47, 15-32.

PNUD, 2009. Province du Sud-Kivu. Profil résumé.Pauvreté et conditions de vie des ménages. Kinshasa : PNUD.

Potgieter M., Tshisikhawe M., Shava S. \& Maroyi A., 2012. Medicinal utilization of exotic plants by Bapedi traditional healers to treat human ailments in Limpopo province, South Africa. J. Ethnopharmacol., 144, 646655.

Rasoanaivo P., 2005. Diversité culturelle et médecine traditionnelle à Madagascar : impasses et opportunités. In: Actes du colloque, Pratiques soignantes, éthique et sociétés : impasses, alternatives et aspects interculturels, 7-9 et 11 avril 2005, Université de Lyon, France.

Reyes-Garcia V. et al., 2006. Cultural, practical and economic value of wild plants: a quantitative study in the Bolivian Amazon. Econ. Bot., 60(1), 62-74.

Richter C., 2015. Biotically induced wood characteristics. In: Richter C., ed. Wood characteristics. Springer International Publishing, 125-174.

Saslis-Lagoudakis C.H. et al., 2014. The evolution of traditional knowledge: environment shapes medicinal plant use in Nepal. Proc. R. Soc. B, 281, 20132768.

Shalukoma C., 2008. Usage des plantes médicinales par les populations riveraines de la partie de haute altitude du Parc National de Kahuzi-Biega, Sud/Kivu, RD Congo. Mémoire de DEA : Université libre de Bruxelles (Belgique).

Signorine M., Piredda M. \& Bruschi P., 2009. Plants and traditional knowledge: an ethno-botanical investigation on Monte Ortoben Nuro, Sardinia. J. Ethnobiol. Ethnomed., 5, 6-20.

Sofowora A., 2010. Plantes médicinales et médecine traditionnelle d'Afrique. Paris : Éditions Karthala.

Sop T.K. et al., 2012. Ethnobotanical knowledge and valuation of woody plants species: a comparative analysis of three ethnic groups from the sub-Sahel of Burkina Faso. Environ. Dev. Sustainability, 14, 627 -649.

Tolossa K. et al., 2013. Ethno-medicinal study of plants used for treatment of human and livestock ailments by traditional healers in South Omo, Southern Ethiopia. J. Ethnobiol. Ethnomed., 9, 32.

Treyvaud-Amiguet V. et al., 2005. A consensus ethnobotany of the Q'eqchi' Maya of southern Belize. Econ. Bot., 59, 29-42.

WHO (World Health Organization), 2002. Traditional medicine strategy 2002-2005. Geneva, Switzerland: WHO.

(45 ref.) 
Appendix 1. List of diseases - Liste des maladies.

\begin{tabular}{|c|c|c|c|c|c|}
\hline Classe & Disease & Vernacular name & Group & $\begin{array}{l}\text { Indicator value } \\
(\%)\end{array}$ & $p^{*}$ \\
\hline \multirow[t]{13}{*}{ Infectious disorders } & Amoebiasis & Eamibe & 1 & 22.5 & 0.0751 \\
\hline & Oral candidiasis & Chaminyagu & 2 & 4.2 & 0.9640 \\
\hline & Cholera & Mukunguru & 2 & 6.7 & 0.3173 \\
\hline & Immunodeficiency & Muzirho & 3 & 6.4 & 0.5145 \\
\hline & Fever & Ihoma & 1 & 1.6 & 10.0000 \\
\hline & Gastroenteritis & Kadurha & 1 & 4.8 & 0.7628 \\
\hline & Hepatitis & Budiku & 3 & 8.7 & 0.3824 \\
\hline & Helminthiasis & Nzoka y’omunda & 1 & 8.1 & 0.4084 \\
\hline & Jaundice & Ensiko & 1 & 1.6 & 10.0000 \\
\hline & Leprosy & Bibenzi & 2 & 20.0 & $0.0060 *$ \\
\hline & Gingivitis & Ndwala y'ekanwa & 1 & 1.6 & 10.0000 \\
\hline & Taeniasis & Tegu & 3 & 9.1 & 0.1461 \\
\hline & Tuberculosis & Chigoholo ch'ikulu & 2 & 6.7 & 0.2933 \\
\hline \multirow[t]{2}{*}{ Circulatory disorders } & Elephantiasis & Birimbo & 3 & 9.1 & 0.1251 \\
\hline & Blood pressure & Ndwala yo murhima & 3 & 5.0 & 0.6316 \\
\hline \multirow[t]{13}{*}{ Digestive disorders } & Tonsillitis & Bilimi & 2 & 6.7 & 0.3253 \\
\hline & Appendicitis & Pandisi & 1 & 1.6 & 10.0000 \\
\hline & Painful bloating of the abdomen & Mukungulo & 1 & 3.2 & 10.0000 \\
\hline & Constipation & Kurhanya & 1 & 1.6 & 10.0000 \\
\hline & Diarrhea & Mushole & 2 & 18.2 & 0.0561 \\
\hline & Bloody diarrhea & Kunya omuko & 3 & 11.9 & 0.1942 \\
\hline & Hyper gastritis & Lurholero lukulu & 1 & 5.7 & 0.6797 \\
\hline & Hypo gastritis & Lurholero lurho & 1 & 3.2 & 10.0000 \\
\hline & Ulcer gastritis & Lurholero lwe chihulu & 2 & 31.3 & $0.0040 *$ \\
\hline & Hemorrhoids & Kukunuka & 2 & 11.9 & 0.1181 \\
\hline & Disc herniation & Omugongo & 3 & 5.9 & 0.5716 \\
\hline & Toothaches & Ndwalay’aminu & 2 & 5.4 & 0.4885 \\
\hline & Painful Bloody diarrhea & Mukunguru & 3 & 4.6 & 0.6907 \\
\hline \multirow[t]{12}{*}{ Genito-urinary disorders } & Adnexitis & Mwanamimba & 1 & 4.8 & 0.7588 \\
\hline & Gonorrhea & Chikagasi & 1 & 3.2 & 10.0000 \\
\hline & Cystitis & Buganga & 2 & 11.9 & 0.1061 \\
\hline & Persistent dysmenorrhea & Ndwala g'Omuko gw'omwezi & 1 & 1.6 & 10.0000 \\
\hline & Frigidity & Kumasha & 1 & 1.6 & 10.0000 \\
\hline & Sexual dysfunction & Kurahasha obuhya & 2 & 38.8 & $0.0010 *$ \\
\hline & Hydrocele & Mishiha & 3 & 6.7 & 0.2132 \\
\hline & Prostate & porositati & 1 & 1.6 & 10.0000 \\
\hline & Uterine prolapse & Ibanzi & 2 & 37.6 & $0.0030 *$ \\
\hline & Male infertility & Kugumba kwe chilume & 1 & 1.6 & 10.0000 \\
\hline & Female infertility & Kugumba kwe chikazi & 3 & 5.6 & 0.6176 \\
\hline & Itchy vaginitis & Chilondatumbu & 2 & 10.7 & 0.1612 \\
\hline \multirow[t]{2}{*}{ Inflammatory diseases } & Burns & Kuhya n'omuliro & 1 & 6.5 & 0.4875 \\
\hline & Nephritis & Nfiko & 1 & 1.6 & 10.0000 \\
\hline
\end{tabular}


Appendix 1 (continued 1). List of diseases - Liste des maladies.

\begin{tabular}{|c|c|c|c|c|c|}
\hline Classe & Disease & Vernacular name & Group & Indicator value (\%) & $p^{*}$ \\
\hline \multirow{2}{*}{ Inflammatory diseases } & Sciatic Nerve & Ihasha & 3 & 9.1 & 0.1251 \\
\hline & Rheumatism & Kugogombaemisi & 1 & 4.1 & 0.8859 \\
\hline \multirow[t]{2}{*}{ Wounds and injuries } & Wounds and injuries & Chihulu chikulu & 3 & 15.7 & 0.0641 \\
\hline & Wounds ulcer & Lukero & 1 & 3.2 & 10.0000 \\
\hline Metabolic disorders & Diabete & Chisukari & 1 & 6.5 & 0.4394 \\
\hline \multirow[t]{3}{*}{ Muscle disorders } & Low back pain & Omugongo & 3 & 9.1 & 0.1221 \\
\hline & Sprain & Kuteguka & 1 & 3.2 & 10.0000 \\
\hline & Fracture & Buvune & 3 & 92.2 & $0.0010^{*}$ \\
\hline \multirow[t]{4}{*}{ Nerve disorders } & Headache & Irhwe kuluma & 3 & 13.4 & 0.0931 \\
\hline & Epilepsy & Lungungu & 1 & 3.4 & 0.9630 \\
\hline & Madness & Isirhe & 1 & 9.1 & 0.6096 \\
\hline & Migraine headaches & Fumba & 2 & 20.2 & $0.0340^{*}$ \\
\hline \multirow[t]{2}{*}{ Poisoning } & Poisoning & Oboge & 1 & 10.6 & 0.3423 \\
\hline & Snake bite & Kajokajoka & 2 & 4.5 & 0.7157 \\
\hline \multirow{6}{*}{ Disorders of pregnancy } & Dystocia & Ukurhagwisa & 3 & 4.8 & 0.6226 \\
\hline & Voluntary termination of pregnancy & Kukulaizimi & 3 & 9.1 & 0.1221 \\
\hline & Threatened abortion & Lumomyo & 2 & 28.0 & $0.0060 *$ \\
\hline & Hypogalactia & Kukumbwa & 1 & 9.7 & 0.3564 \\
\hline & Fontanel & Lukunga & 3 & 21.2 & $0.0130 *$ \\
\hline & Fetal death & Chibolwe & 2 & 6.7 & 0.2933 \\
\hline \multirow[t]{7}{*}{ Respiratory disorders } & Anginas & Bigoga & 1 & 3.2 & 10.0000 \\
\hline & Asthma & Obuhema & 1 & 3.2 & 10.0000 \\
\hline & Coryza & Kufuneka & 1 & 1.6 & 10.0000 \\
\hline & Cough & Chikoholo & 2 & 4.5 & 10.0000 \\
\hline & Pain of chest & Kashiha & 3 & 6.7 & 0.3263 \\
\hline & Pneumonia & Mwijimbwe & 1 & 3.2 & 10.0000 \\
\hline & Sinusitis & Muzerezi & 2 & 6.7 & 0.2933 \\
\hline \multirow[t]{2}{*}{ Sensory disorders } & Cataracts & Nshongo & 1 & 4.8 & 0.6396 \\
\hline & Conjunctivitis & Ndwala ya masu & 1 & 6.5 & 0.4384 \\
\hline \multirow{7}{*}{$\begin{array}{l}\text { Skin and subcutaneous } \\
\text { disorders }\end{array}$} & Abscess & Muhama & 1 & 8.1 & 0.4124 \\
\hline & Dermatosis & Kuyaga & 1 & 8.1 & 0.4284 \\
\hline & Furunculosis & Mahurehure & 3 & 6.7 & 0.3063 \\
\hline & Cyst & Muziha & 2 & 5.4 & 0.4795 \\
\hline & Fungus & Lubenja & 3 & 8.0 & 0.1361 \\
\hline & Panari & Mududu & 3 & 6.7 & 0.3073 \\
\hline & Psoriasis & Pessé & 2 & 5.4 & 0.4625 \\
\hline \multirow[t]{4}{*}{ Abnormal blood organs } & Anemia & Kubulaomuko & 2 & 3.9 & 10.0000 \\
\hline & Splenomegaly & Lusingu & 3 & 4.9 & 0.6697 \\
\hline & Tumor Breast & $\begin{array}{l}\text { Chimokomoko, } \\
\text { Mpanga }\end{array}$ & 1 & 3.2 & 10.0000 \\
\hline & Cancer unidentified seat & Kafinjo & 1 & 1.6 & 10.0000 \\
\hline \multirow[t]{2}{*}{ Nutritional disorders } & Anorexia & Kurhahasha kulya & 2 & 6.7 & 0.3173 \\
\hline & Emaciation & Njorwe & 1 & 1.6 & 10.0000 \\
\hline
\end{tabular}


Appendix 1 (continued 2). List of diseases - Liste des maladies.

\begin{tabular}{|c|c|c|c|c|c|}
\hline Classe & Disease & Vernacular name & Group & Indicator value (\%) & $p^{*}$ \\
\hline Nutritional disorders & Malnutrition & Obwaki & 1 & 3.2 & 10.0000 \\
\hline \multirow[t]{2}{*}{ Poorly defined syndromes } & Epistaxis & Muledu & 1 & 1.6 & 10.0000 \\
\hline & Vertigo & Chizunguzungu & 1 & 3.2 & 10.0000 \\
\hline \multirow[t]{8}{*}{ Cultural syndromes } & Kivubo & Chivubo & 1 & 3.2 & 10.0000 \\
\hline & Iseke & Iseke & 1 & 1.6 & 10.0000 \\
\hline & Kunde & Kunde & 2 & 6.7 & 0.2903 \\
\hline & Curses & Mugereko & 1 & 1.6 & 10.0000 \\
\hline & Evil spirit & Mudorho & 1 & 4.8 & 0.7618 \\
\hline & Mpivu & Mpivu & 1 & 1.6 & 10.0000 \\
\hline & Mulonge & Mulonge & 1 & 6.5 & 0.5075 \\
\hline & Mukinje & Mukinje & 1 & 1.6 & 10.0000 \\
\hline
\end{tabular}

* : indicator species of the groupe (Indval method) - espèce indicatrice du groupe (méthode Indval); meaning of the groups - signification des groupes: see figure 5 - voir figure 5 .

Appendix 2. Floral list - Liste floristique.

\begin{tabular}{|c|c|c|c|c|c|c|c|}
\hline Family & Species & Vernacular name & Group & $\begin{array}{l}\text { Indicator } \\
\text { value }\end{array}$ & $p^{*}$ & $\begin{array}{l}\text { Morpho- } \\
\text { logical } \\
\text { type }\end{array}$ & Habitat \\
\hline Alangiaceae & $\begin{array}{l}\text { Alangium chinense (Lour.) } \\
\text { Harms }\end{array}$ & Mulemera & 1 & 3.3 & 10.000 & tree & forest \\
\hline Apocynaceae & Baissea multiflora A.DC. & Mpango & 1 & 14.7 & $0.049^{*}$ & shrub & forest \\
\hline Apocynaceae & $\begin{array}{l}\text { Pleiocarpa pycnantha } \\
\text { (K.Schum.) Stapf }\end{array}$ & Kintangondo & 2 & 3.9 & 0.672 & tree & forest \\
\hline Apocynaceae & $\begin{array}{l}\text { Tabernaemontana johnstonii } \\
\text { (Stapf) Pichon }\end{array}$ & Muberebere & 3 & 16.6 & 0.076 & tree & forest \\
\hline Araliaceae & Polyscias fulva (Hiern) Harms & Ntongi & 1 & 2.2 & 0.988 & tree & forest \\
\hline Asclepiadaceae & $\begin{array}{l}\text { Periploca linearifolia Quart.- } \\
\text { Dill. \& A.Rich. }\end{array}$ & Kanondonondo & 2 & 1.8 & 10.000 & vine & ruderal \\
\hline Asteraceae & $\begin{array}{l}\text { Mikania cordata (Burm.f.) } \\
\text { B.L.Rob. }\end{array}$ & $\begin{array}{l}\text { Muhombia } \\
\text { mashaka }\end{array}$ & 1 & 12.5 & 0.163 & herb & forest \\
\hline Asteraceae & Ageratum conyzoides $(\mathrm{L}.) \mathrm{L}$. & Kahyola & 2 & 22.1 & $0.004 *$ & herb & fallow \\
\hline Asteraceae & Alchornea hirtella Benth. & Lulerhalerha & 2 & 14.3 & $0.036^{*}$ & shrub & forest \\
\hline Asteraceae & $\begin{array}{l}\text { Anisopappus africanus } \\
\text { (Hook.f.) Oliv. \& Hiern }\end{array}$ & Nyamwasamuza & 2 & 21.4 & $0.004 *$ & herb & fallow \\
\hline Asteraceae & Bidens pilosa $\mathrm{L}$. & Kashisha & 2 & 23.9 & $0.012 *$ & herb & fallow \\
\hline Asteraceae & $\begin{array}{l}\text { Conyza aegyptiaca }(\mathrm{L} .) \\
\text { Dryand. ex Aiton }\end{array}$ & Nyambuba & 2 & 5.7 & 0.647 & herb & fallow \\
\hline Asteraceae & Lactuca attenuata Stebbins & Luvunanga & 2 & 9.3 & 0.130 & herb & forest \\
\hline Asteraceae & Vernonia amygdalina Delile & Mwibirizi & 2 & 3.6 & 0.645 & tree & ruderal \\
\hline Asteraceae & $\begin{array}{l}\text { Vernonia hochstetteri Sch.Bip. } \\
\text { ex Hochst. }\end{array}$ & Ivumovumo & 2 & 10.1 & 0.141 & shrub & forest \\
\hline Asteraceae & Vernonia kirungae R.E.Fr. & Ivumo & 2 & 7.3 & 0.305 & shrub & forest \\
\hline Asteraceae & $\begin{array}{l}\text { Alchornea cordifolia } \\
\text { (Schumach. \& Thonn.) Müll. } \\
\text { Arg. }\end{array}$ & Lungusu & 3 & 4.1 & 0.469 & shrub & forest \\
\hline
\end{tabular}


Appendix 2 (continued 1). Floral list - Liste floristique.

\begin{tabular}{|c|c|c|c|c|c|c|c|}
\hline Family & Species & Vernacular name & Group & $\begin{array}{l}\text { Indicator } \\
\text { value }\end{array}$ & $p^{*}$ & $\begin{array}{l}\text { Morpho- } \\
\text { logical } \\
\text { type }\end{array}$ & Habitat \\
\hline Asteraceae & $\begin{array}{l}\text { Dichrocephala integrifolia } \\
\text { (L.f.) Kuntze }\end{array}$ & Chitundambuga & 3 & 12.1 & 0.2710 & herb & fallow \\
\hline Asteraceae & $\begin{array}{l}\text { Crassocephalum bumbense } \\
\text { S.Moore }\end{array}$ & Chifubula & 4 & 9.9 & 0.1850 & herb & forest \\
\hline Basellaceae & Basella alba $\mathrm{L}$. & Ndelama & 1 & 13.7 & 0.0640 & herb & forest \\
\hline Begoniaceae & Begonia meyeri-johannis Engl. & Kahulula & 2 & 17.3 & $0.0200 *$ & herb & forest \\
\hline Burseraceae & Canarium schweinfurtii Engl. & Bwaga & 1 & 7.4 & 0.3280 & tree & forest \\
\hline Caryophyllaceae & $\begin{array}{l}\text { Drymaria cordata Willd. ex } \\
\text { Schult. }\end{array}$ & Bwahulo & 4 & 41.0 & $0.0010^{*}$ & herb & ruderal \\
\hline Chrysobalanaceae & Parinari excelsa Sabine. & Mwinga & 2 & 18.5 & $0.0160 *$ & tree & forest \\
\hline Clusiaceae & Harungana montana Spirlet & Kadwamuko & 1 & 12.4 & 0.2200 & shrub & forest \\
\hline Clusiaceae & Symphonia globulifera L.f. & Muzimba & 1 & 3.3 & 1.0000 & tree & forest \\
\hline Clusiaceae & Lebrunia bushaei Staner & Bushahi & 2 & 7.1 & 0.1620 & tree & forest \\
\hline Convolvulaceae & Ipomoea involucrata P.Beauv. & Kadwamonka & 1 & 10.0 & 0.1210 & herb & forest \\
\hline Cyatheaceae & Cyathea manniana Hook. & Bishembegere & 1 & 3.5 & 0.7420 & shrub & forest \\
\hline Euphorbiaceae & $\begin{array}{l}\text { Macaranga kilimandscharica } \\
\operatorname{Pax}\end{array}$ & Lushasha & 2 & 4.9 & 0.3140 & tree & forest \\
\hline Euphorbiaceae & Neoboutonia macrocalyx Pax & Chibirabira & 2 & 8.2 & 0.1990 & tree & forest \\
\hline Euphorbiaceae & Tragia brevipes Pax & Ishusha & 3 & 35.4 & $0.0010 *$ & shrub & ruderal \\
\hline Euphorbiaceae & $\begin{array}{l}\text { Neoboutonia africana Müll. } \\
\text { Arg. }\end{array}$ & Kitubutubu & 4 & 5.2 & 0.5880 & tree & forest \\
\hline Fabaceae & $\begin{array}{l}\text { Piptadeniastrum africanum } \\
\text { (Hook.f.) Brenan }\end{array}$ & Libuyu & 1 & 3.3 & 10.0000 & tree & forest \\
\hline Fabaceae & Millettia psilopetala Harms & Nshungurhi & 2 & 8.7 & 0.1300 & tree & forest \\
\hline Fabaceae & $\begin{array}{l}\text { Newtonia buchananii (Baker) } \\
\text { G.C.C.Gilbert \& Boutique }\end{array}$ & Lukundu & 2 & 1.8 & 10.0000 & tree & forest \\
\hline Fabaceae & $\begin{array}{l}\text { Albizia gummifera (J.F.Gmel.) } \\
\text { C.A.Sm. }\end{array}$ & Mushebere & 3 & 3.3 & 0.6690 & tree & forest \\
\hline Fabaceae & $\begin{array}{l}\text { Erythrophleum guineense } \\
\text { G.Don }\end{array}$ & Chikubwekubwe & 3 & 2.9 & 0.9130 & tree & forest \\
\hline Labiataceae & $\begin{array}{l}\text { Clerodendrum welwitschii } \\
\text { Gürke }\end{array}$ & Nfubya & 2 & 17.9 & $0.0060 *$ & shrub & forest \\
\hline Lamiaceae & $\begin{array}{l}\text { Pycnostachys erici-rosenii } \\
\text { R.E.Fr. }\end{array}$ & Mwizunguluka & 2 & 7.2 & 0.3650 & shrub & forest \\
\hline Lauraceae & Persea americana Mill. & Ivocati & 2 & 9.5 & 0.2890 & tree & cultivated \\
\hline Lobeliaceae & Lobelia giberroa Hemsl. & Mwirumbu & 3 & 5.4 & 0.3910 & shrub & forest \\
\hline Malvaceae & Hibiscus noldeae Baker f. & Mukerashungwe & 3 & 20.2 & $0.0280 *$ & herb & forest \\
\hline Meliaceae & Carapa grandiflora Sprague & Bugwerhe & 2 & 26.2 & $0.0030 *$ & tree & forest \\
\hline Meliaceae & $\begin{array}{l}\text { Entandrophragma excelsum } \\
\text { (Dawe \& Sprague) Sprague }\end{array}$ & Libuyu & 2 & 17.9 & $0.0200 *$ & tree & forest \\
\hline Moraceae & Ficus oreodryadum Mildbr. & Mulehe & 2 & 8.2 & 0.2030 & tree & forest \\
\hline Moraceae & Ficus thonningii Blume & Kahura & 2 & 3.6 & 0.6930 & tree & forest \\
\hline Moraceae & $\begin{array}{l}\text { Milicia excelsa (Welw.) } \\
\text { C.C.Berg }\end{array}$ & Muvula & 2 & 1.8 & 10.0000 & tree & forest \\
\hline
\end{tabular}


Appendix 2 (continued 2). Floral list - Liste floristique.

\begin{tabular}{|c|c|c|c|c|c|c|c|}
\hline Family & Species & Vernacular name & Group & $\begin{array}{l}\text { Indicator } \\
\text { value }\end{array}$ & $p^{*}$ & $\begin{array}{l}\text { Morpho- } \\
\text { logical } \\
\text { type }\end{array}$ & Habitat \\
\hline Moringaceae & Moringa oleifera Lam. & Muringa & 3 & 5.3 & 0.4470 & tree & cultivated \\
\hline Musaceae & $\begin{array}{l}\text { Ensete ventricosum (Welw.) } \\
\text { Cheesman }\end{array}$ & Chirembo & 3 & 21.2 & $0.0110 *$ & herb & forest \\
\hline Myrsinaceae & Embelia schimperi Vatke & Kashalulabahivi & 1 & 5.5 & 0.5850 & vine & forest \\
\hline Myrsinaceae & $\begin{array}{l}\text { Rapanea melanophloeos (L.) } \\
\text { Mez }\end{array}$ & Chishorhe & 1 & 3.3 & 1.0000 & tree & forest \\
\hline Myrsinaceae & Maesa lanceolata Forssk. & Mparhi & 4 & 31.8 & $0.0020 *$ & tree & forest \\
\hline Myrtaceae & $\begin{array}{l}\text { Syzygium guineense (Willd.) } \\
\text { DC. }\end{array}$ & Chikobarhi & 2 & 7.1 & 0.1470 & tree & forest \\
\hline Myrtaceae & $\begin{array}{l}\text { Syzygium cordatum Hochst. ex } \\
\text { Krauss }\end{array}$ & Mugorhe & 3 & 27.0 & $0.0070 *$ & tree & forest \\
\hline Olacaceae & Strombosia scheffleri Engl. & Busika & 3 & 4.1 & 0.5610 & tree & forest \\
\hline Oleaceae & $\begin{array}{l}\text { Jasminum abyssinicum Hochst. } \\
\text { ex DC. }\end{array}$ & Kafufula & 2 & 3.6 & 0.6590 & vine & forest \\
\hline Phyllanthaceae & $\begin{array}{l}\text { Bridelia micrantha (Hochst.) } \\
\text { Baill. }\end{array}$ & Mujimbu & 2 & 8.1 & 0.2520 & tree & forest \\
\hline Piperaceae & Piper capense L.f. & Muborobondo & 2 & 21.9 & $0.0160 *$ & shrub & forest \\
\hline Plantaginaceae & Plantago palmata Hook.f. & Chibarama & 1 & 19.2 & $0.0330 *$ & herb & ruderal \\
\hline Polygonaceae & Rumex bequaertii De Wild. & Muberanaga & 1 & 7.8 & 0.3050 & herb & forest \\
\hline Rhamnaceae & Gouania longispicata Engl. & Muvurha & 2 & 8.4 & 0.2670 & vine & forest \\
\hline Rosaceae & $\begin{array}{l}\text { Prunus africana ( Hook.f.) } \\
\text { Kalkman }\end{array}$ & Muhumbahumba & 4 & 12.7 & 0.0500 & tree & forest \\
\hline Rubiaceae & Galiniera coffeoides Delile & Chintindi & 2 & 7.1 & 0.1460 & shrub & forest \\
\hline Rubiaceae & Rubia cordifolia $\mathrm{L}$. & Lukerabatuzi & 2 & 7.1 & 0.1510 & herb & forest \\
\hline Rubiaceae & $\begin{array}{l}\text { Tricalysia niamniamensis } \\
\text { Schweinf. ex Hiern }\end{array}$ & Nkongo & 2 & 10.7 & 0.1040 & shrub & forest \\
\hline Rubiaceae & Coffea kivuensis Lebrun & Akahwa & 3 & 6.2 & 0.3710 & shrub & forest \\
\hline Rubiaceae & $\begin{array}{l}\text { Hallea rubrostipulata } \\
\text { (K.Schum.) J.-F.Leroy }\end{array}$ & Muzibaziba & 3 & 3.5 & 0.8610 & tree & forest \\
\hline Rutaceae & $\begin{array}{l}\text { Zanthoxylum macrophyllum } \\
\text { Nutt. }\end{array}$ & Kashabumbu & 2 & 9.0 & 0.2310 & tree & forest \\
\hline Rutaceae & $\begin{array}{l}\text { Zanthoxylum lemairei (De } \\
\text { Wild.) P.G.Waterman }\end{array}$ & Kashabumbu & 3 & 17.8 & $0.0160 *$ & tree & forest \\
\hline Sapotaceae & $\begin{array}{l}\text { Autranella congolensis (De } \\
\text { Wild.) A.Chev. }\end{array}$ & Mulungu & 2 & 7.1 & 0.1550 & tree & forest \\
\hline Simaroubaceae & Kirkia acuminata Oliv. & $\begin{array}{l}\text { Mulumear- } \\
\text { hashonwako }\end{array}$ & 3 & 15.8 & $0.0220 *$ & tree & forest \\
\hline Tiliaceae & Triumfetta cordifolia A.Rich. & Chahunga & 2 & 7.1 & 0.1460 & shrub & forest \\
\hline Ulmaceae & Trema orientalis (L.) Blume & Mushakushaku & 4 & 37.1 & $0.0010 *$ & tree & forest \\
\hline Urticaceae & $\begin{array}{l}\text { Urera hypselodendron (Hochst. } \\
\text { ex A.Rich.) Wedd.. }\end{array}$ & Mushebere & 1 & 11.0 & 0.0950 & vine & forest \\
\hline Urticaceae & Myrianthus holstii Engl. & Bwamba & 2 & 17.9 & $0.0100 *$ & tree & forest \\
\hline Xanthorrhoeaceae & Aloe barbadensis Mill. & Chigaka & 1 & 28.6 & $0.0020 *$ & herb & cultivated \\
\hline
\end{tabular}

* : indicator species of the groupe (Indval method) - espèce indicatrice du groupe (méthode Indval); meaning of the groups - signification des groupes: see figure 5 - voir figure 5 . 